\title{
"Factors Influencing Youth Juvenile Delinquency at Blue Hills Children's Prison Rehabilitation Centre in Gweru, Zimbabwe: An Explorative Study"'
}

\author{
Benjamin Mambende', Thelma Nyandoro², Levison Maunganidze ${ }^{3}$, Abigirl Sawuti ${ }^{4}$ \\ Midlands State University, P. Bag 9055 Gweru, Zimbabwe \\ ${ }^{1}$ mambendeb@msu.ac.zw, ${ }^{2}$ thelmanyandoro@gmail.com \\ ${ }^{3}$ levisonmaunganidze@yahoo.com, ${ }^{4}$ abigirlsawuti@gmail.com
}

\begin{abstract}
The study explored factors that influence youth juvenile delinquency at Blue Hills Children's Prison Rehabilitation Centre in Gweru which is one of penal institutions for young male and female offenders aged 11 17 years in Zimbabwe. Eight male and one female participant were identified and recru ited through purposive sampling method. Data was collected by the use of personal interviews. The thematic approach was used to analyze the data gathered. Results indicated that juvenile delinquency was influenced by lack of parental attachment, broken homes, the authoritative parenting style and poverty. It was concluded that the family and home environment have a great influence on the development of a child and subsequently on creating a delinquent predisposition.
\end{abstract}

Keywords : Juvenile delinquency; minors; family; family environment; rehabilitation

\section{INTRODUCTION}

Juvenile delinquency refers to antisocial behaviors of youths. Herrenkohl (2000) defines delinquency as a set of behaviors that are not in line with the collective practices and/or ethics of the dominant social group. The antisocial behaviors often associated with the juvenile delinquents include vandalism, drug abuse, weapon carrying, alcohol abuse, rape, examination malpractices, school violence, bullying, cultism, truancy, school drop-outs, to mention but a few (Farrington, 1991).

Juvenile delinquency is a very prevalent social problem worldwide. In the 1990s the number of juvenile offenders in Western Europe increased by 50\% as compared to 30\% in Eastern Europe and the Commonwealth independent states (World Youth Report, 2003). Patterns and trends of juvenile crimes can be worse in developing countries such as Zimbabwe that is reeling under economic hardships and poverty, and a country where the extended family concept is held in high regard.

The macro-economic situation and HIV/AIDS pandemic in Zimbabwe has led to the deterioration of the family unit. Families are breaking down with parents migrating overseas in search of greener pastures and this has subsequently led to an increase in single parent headed families, children living with extended family, and in extreme cases child headed families. Today, however, with the rising divorce rate, increase in teen pregnancy, and prevalence of single-parent households, the definition of family has changed, a situation that has probably left many children at risk of becoming de linquent (Zill 2003).To add on, Zimbabwe is currently grappling with one of the highest unemployment rates, and many families are struggling to generate income, a situation that is driving children to fend for themselves, sometimes through criminal activities.

The study therefore seeks to explore the factors associated with juvenile delinquency for children at a penal institution, in this case, Blue Hills children's prison in Gweru. The intensity and severity of juvenile offences are generally determined by the social, economic and cultural conditions prevailing in a country. Juveniles' choice of delinquent careers and the consequent perpetuation of delinquency are fostered by a wide range of factors.

\subsection{Factors Influencing Juvenile Delinquency}

Many authorities have examined the factors that influence juvenile delinquency, among themSavignac (2009) in the United States; Fischer (1984) in Europe and Ngale (2009) in Lesotho. Savignac's (2009) study revealed that there are three groups of factors associated with delinquency: factors related to 
family dynamics and function such as family conflict; factors related to family characteristics such as single parenthood or family income; and protective factors such as parents' level of education and stability of the family unit. Whereas Savignac's study was carried out in the United States where the economic situation is relatively stable, the current study was conducted in a deteriorating economic context in Zimbabwe and where the traditional extended family value is still upheld.

Omboto et al. (2012) found other factors associated with delinquency and these are poverty, and the use of drugs. Fischer (1984) found out that a large family size is a relatively strong and highly replicable predictor of delinquency. According to Farrington (1992) large family size predicted selfreported delinquency as well as convictions.

Brownfield and Sorenson (1994) reviewed several possible explanations for the link between large family size and delinquency, including those focusing on features of the parents (e.g., criminal parents, teenage parents), those focusing on parenting (e.g., poor supervision, disrupted families), and those focusing on economic deprivation or family stress. Interestingly Farrington (1992) suggested that birth order is another key factor to delinquency.However indications are that most studies on delinquency have been carried out in Western countries with only a few researches having been conducted in an African context such as Zimbabwe where the family unit, big families and the extended family are highly esteemed.

\subsection{Child Rearing Methods as a Contributory Factor to Juvenile Delinquency}

Many different types of child-rearing methods may predict a child's delinquency. For Farrington (1992) the most important dimensions of child-rearing are supervision or monitoring of children, discipline or parental reinforcement, warmth or coldness of emotional relationships, and parental involvement with children. Parental supervision, however, ranks very high in predicting child delinquency (Farrington \& Loeber, 1999; Smith \& Stern, 1997). Yet it appears that focus in most psychological studies has been on parental styles such as those styles advanced by Baumrind (1966) at the expense of parental practices. Theoretically the link between child-rearing methods and delinquency focus on social learning or attachment theories. Social learning theories suggest that children's behavior depend on parental rewards and punishments and on the models of behavior that parents present (Patterson, 1995). On the other hand John Bowlby suggests that children who are not emotionally attached to warm, loving, and law-abiding parents will tend to become delinquent.

\subsection{Parental Conflict and Dis rupted Families as a Pre dictor of Juvenile Delinquency}

John Bowlby (1951) popularized the theory that broken homes cause delinquency. He argued that mothers' love in infancy and childhood was just as important for mental health as were vitamins and proteins for physical health. If a child suffered a prolonged period of maternal deprivation during the first 5 years of life, this would have irreversible negative effects, including becoming a cold "affectionless character" and a delinquent. By the same token, for example, it was generally found out that children who are separated from a biological parent are more likely to commit crime than children from intact families, Kolvin et al. (1988).

As mentioned earlier on most studies and researches which try to link different family factors to juvenile delinquency have been carried out in developed countries with few studies being carried out in Zimbabwe. The research attempts to find out the link between family environment and juvenile delinquency in a Zimbabwean context.

\section{RESEARCH QUESTIONS}

a)Do child rearing methods or parental styles contribute to juvenile delinquency?

b) Is family criminality a predictor of juvenile delinquency?

c) How does parental conflict and disrupted family situations influence juvenile delinquency?

\section{METHOD}

A qualitative, descriptive, explorative and contextual research design was used to investigate factors that influence youth juvenile delinquency at a Youth Correctional Centre, Blue Hills, in Gweru. Qualitative research was used as a way of gaining insights through discovering meaning, exploring the depth, richness and complexity inherent in the phenomenon (Burns \& Grove, 1993). In this study a detailed picture of the factors influencing youth juvenile delinquency were described as experienced 
by youths themselves. The explorative design enabled exploration of factors influencing youth juvenile delinquency which were relatively unknown. This study was contextual because it was executed within the context of juvenile delinquency at a youth rehabilitation Centre in Gweru.

\subsection{Participants}

The researcher conducted in-depth interviews with nine delinquents who are being rehabilitated at Blue Hills, a penal institution in Gweru. The study involved 9 participants aged between 11 and 17 years with a mean age of 15 years.

\subsection{In-Depth Interviews}

These were used to collect data from the participants. In-depth and face-to- face interviews were preferred because they enabled the researchers to gather detailed information about the peculiar juvenile situations of each participant. The interviews enabled all necessary clarifications to be made through follow-up questions.

\subsection{Procedures}

The researchers informed the Blue Hills Young Offenders Prison inmatesof the study. The offenders had already been selected with the help of rehabilitation officers working at the institution and who had been given the selection criteria well in advance. The 9 juvenile delinquents were interviewed by the researchers. Open ended questions and probeswere used and these enabled the researchers to fully explore the experiences of these young offenders. The research was done with close observation of research ethics. The interview environment was a closed, quiet room to enhance privacy for the participant as well as to facilitate effective data gathering without any disturbances. The interviews enabled the researchers to pay attention to non-verbal cues and emotions of the interviewees. Interviews sessions were recordedby means of note taking as well as on the researchers' mobile phone. Each interview session took about thirty to forty minutes and no participant withdrew from the sessions although they were informed of their right to do so whenever they wanted to. Interviews were conducted in English and Shona and the results were all translated into English.

All the researchers, in line with Haas et al.'s (2004) recommendations, took down notes derived from observations and these notes assisted researchers during the data analyses phase. The following ethical principles were considered: ethical approval from the prison administrators; informed consent and voluntary participation; protection of participants from both psychological and physiological harm and confidentiality.

\subsection{Data Analysis}

The thematic approach was used to analyze the data gathered. According to Braun and Clarke (2006) thematic analysis is a qualitative analytic method for identifying, analyzing and reporting patterns (themes) within. Braun and Clarke (2006) also articulated that thematic analys is is an approach to dealing with data that involves the creation and application of 'codes' to data. Coding refers to the creation of categories in relation to data; the grouping together of different instances of datum under an umbrella term that can enable them to be regarded as of the same type. The information was grouped into different categories and analyzed using the themes that the data will be representing.

The researchers chose the thematic approach because it provided a means of organizing and summarizing the large body of findings. Moreover, the thematic approach was preferred because themes capture recurrent issues raised by the participants.

\section{ReSUlts}

\subsection{The me 1: The Impact of B roken Homes on Juvenile Delinque ncy}

During the interview the researcher noted that certain respondents were coming from broken homes. Some of the respondents were living within homes where there was conflict within the family, a distinct lack of parent-child attachment, instability, poor home life quality, others were orphans, and others did not even know the whereabouts of their parents.

For example Participant 7's parents divorced and he stated that he was being constantly moved from one relative to another. During the interview he stated that: 
"My parents divorced when I was still very young and from there on I have been constantly moved from one household to another. I grew up in different households ...."

The researcher noted that the child never really settled down with one family and was being moved from one household to another. He never really developed an attachment with either of his parents or caregiver and this may have caused confusion and caused the child to behave in a delinquent manner.

Another example of a broken home can be noted by looking at Participant 5 who stated that:

"My parents were always arguing. My father always beat me and my mother when he came home drunk..... And when my father was at work my mother would disappear for hours, rumor had it that she was having an affair with a certain man who lived in our neighborhood. I pretended not to see what was happening but I could not take it any more so I decided to go and live in the streets....... I also stole from my aunt's shop with my friends....."

It can be noted that participant 5 came from a broken home. He stated that his parents were always fighting and it seems they had found new partners although they were still living under the same roof. The situation at home became stressful for the child and he decided to run away and live in the streets. When he decided to live in the streets he found corrupt accomplices whom he became close to. These friends taught the participant to engage in criminal behavior.

\subsection{Sub Theme 1: The Effect of Negligence on Children}

The issue of broken homes can also be linked to the issue of neglect. Parents or caregivers are supposed to be there for their children and be supportive however when parents or families do not play their role this may have adverse effects on the development and wellbeing of a child. This can be demonstrated by what was said by participant 1 .

".........my parents are both dead. My mother died when I was born and my father denied my existence. Before I came to Blue Hills I was staying in Bikita with my uncle's family. My aunt always ill-treated me, favoured her own children and most of the time I had to go to bed or to school on a hungry stomach...... I was ignored and neglected ........."

Participant number 1 showed intense hurt because his aunt ill-treated him and this was worsened by the fact that he never knew his mother. This might have caused him to behave in a delinquent manner.

\subsection{The me 2: Poverty as a Contributory Factor to Juvenile Delinquency}

Poverty was repetitively mentioned as a factor in juvenile delinquency. Some of the respondents stated that they came from poor backgrounds and others were children living on the streets. It seems that financial problems drove them to commit crimes. Most of the respondents were at the rehabilitative institution because they had been convicted for theft.

For example, participant number 9 stated that,

"I was convicted for 4 counts of theft and unlawful entry. I am a double orphan and when my parents died none of our relatives wanted to take care of us. We then went to stay with our maternal grandmother in Masembura who was now too old to fend for us. I was left to fend for myself and my younger brother and life was very difficult for us. We stopped going to school because there was no one to pay our fees and we used the time to do part time jobs (maricho) like cultivating for people and we were paid in the form of maize meal but this was not enough to sustain us. So I began stealing from people 's households at night."

Participant number 9 has clearly showed that he was driven to being a delinquent because of poverty. His parents died and they were living with a caregiver who was now too old to look after them and they had to find a way to survive so he decided to steal.

Respondent 3 stated that both of his parents were alive, however, they were HIV positive and sometimes one of them got so sick that they would be bedridden for weeks and sometimes even months. The respondent also stated that his parents were unemployed and they were struggling to make ends meet. He mentioned that they were a poor family and the situation was worsened by the fact that they were HIV positive - a situation that pushed respondent 3 to be convicted for theft.

\subsection{Theme 3: Lack of Attachment as a Contributory Factor to Juvenile Delinquency}

It can be noted that as stated by Bowlby in his attachment theory that a child who is deprived of motherly love and care in the first five years of their live is more likely to become a delinquent. There 
was evidence that attachment in early childhood seems to influence the behavior of a child. For example participant 8 (the only female respondent) stated that her mother died when she was 3 and she grew up staying with her father and stepmother.

"My mother died when I was 3 years old, I grew up with my stepmother who constantly reminded me that she was not my real mother. I don't even remember how my real mother looked like. My father was always at work and I never really bonded with any of my family members."

This respondent lacked attachment in early life, his mother died and his father did not care much for her. This may have caused trauma and psychological problems as the child was growing up because he felt unloved and unwanted. This consequently resulted in him having the feelings of wanting to hurt someone else. This participant was convicted for theft.

Attachment is a psychological connectedness that occurs between humans and lasts for a long period of time. According to the attachment theory by Bowlby when babies are able to establish warm loving relationships with the ir mothers or caregivers, the pleasure they derive from this association motivates them to try to establish friendly relationships with other people. Nevertheless the deprivation of this maternal care has its negative impacts on the child.

\subsection{The me 4: Family Criminality as a Predictor of Juvenile Delinquency}

The researcher noted that there is a greater risk or chance of a child being convicted for crime when there is a family member who has committed a crime before. Looking at participant 2 he was brought to Blue Hills because he was convicted for theft and there had been several cases of bullying at school which were reported. During the discussion he mentioned that his father had been convicted for rape in 2008 and he was currently serving his sentence at Chikurubi Prison.

"..... I was shocked and hurt when my mother told me that my father had raped our younger sister. He is currently serving his sentence at Chikurubi prison. We are 3 children in ourfamily and I am the only boy."

\subsection{Theme 5: The Effects of Pare nting Styles on Juvenile Delinquency}

This study noted that certain parenting styles seemingly have an influence on juvenile delinquency. If a child has authoritarian parents then they are at a greater risk of developing into delinquents. This is exemplified by participant 5 who stated that:

“.........my father was really harsh on us. One silly mistake would deserve an inten se beating. He used to beat us with an electric cord and there was no time for negotiation".

\section{DisCUSSION}

The study was undertaken to explore the influence of family life and home environment on juvenile delinquency for young offenders at Blue Hills prison Rehab in Gweru. The aspects of the children's experiences that were taken into consideration include whether attachment has a direct effect on juvenile delinquency, the probability of child coming from a dysfunctional family turning into a violent crime offender, how poverty plays a role in causing juvenile delinquency and the effects of parenting styles on juvenile delinquency. Findings are discussed according to these aspects.

\subsection{Does Attachment Play a Role in Delinquency?}

In this study, one of the research questions was whether attachment played a role in delinquency. This research question was answered in that the researcher established that children who lacked parental attachment in their early lives were at a higher risk of developing into juvenile delinquents. For example, some respondents lost their mothers very early in life for example participant 1 stated that his mother died at his birth and his father denied his existence and he stated that he felt 'unloved and unwanted' hence this can be said to have influenced the child's criminal behavior. This is supported by John Bowlby (1951), who popularized the theory that broken homes cause delinquency. He argued that motherly love in infancy and childhood was just as important for mental health as were vitamins and proteins for physical health. He thought that it was essential that a child should experience a warm, loving, and continuous relationship with a mother figure. If a child suffered a prolonged period of maternal deprivation during the first 5 years of life, this would have irreversible negative effects, 
including becoming a cold "affectionless character" and a delinquent. This theory is in line with the research findings which suggest that a child who does not develop an attachment early in life with their parents or caregiver is more likely to develop into a delinquent.

The above finding is consistent with early research findings by Anna Freud and Dorothy Burlingham in 1953 from their nursery in Hampstead; they found out that children deprived of maternal care may be seriously affected in the ir physical, intellectual, emotional and social development and tend to be delinquent.

\subsection{The Influence of the Type of Family on Juvenile Delinquency}

This research revealed that most children who came from broken homes were prone to commit crime. Some of the respondents indicated that they were coming from homes where there was conflict within the family for example participant 5 indicated that there was parental conflict in his family. This assertion that children from broken homes are more likely to commit crime is supported by Brownfield and Sorenson (1996), who stated that there are some theories which argue that disrupted families produce delinquent children. Broken homes often promote delinquency because of risk factors such as parental conflict, criminal or antisocial parents, low family income, or poor childrearing methods rampant in such families.

It was also reviewed in the study that child neglect plays a role in influencing juvenile delinquency. This is also supported by Grove et al (1990), they stated that children who are physically abused or neglected tend to become offenders later in life The most famous study of this was carried out by Widom (1989) in Indianapolis and it showed that the children who were abused or neglected were more likely to be arrested as juveniles and as adults.

Furthermore, in this study it was also reviewed that a child who had a parent who had committed a crime before was also more likely to also commit a crime. This was supported by the Pittsburgh Youth Study, it was suggested that arrested fathers tended to have delinquent sons because they tended to impregnate young women, to live in bad neighborhoods, and to use child-rearing methods that did not develop a strong conscience in their children (Farrington et al., 2001). In the Cambridge Study, West and Farrington (1973) suggested that poor parental supervision was one link in the chain between criminal fathers and delinquent sons.

\subsection{Does Poverty Insinuate Juvenile Delinquency?}

It was found in this study that participants who came from poor families were more likely to engage in crime. For example looking at participant 9 who clearly stated that he was driven to commit crime because of poverty, his parents had died and he was living with a caregiver who was now too old to fend for him and his younger brother, so they had to find a way to survive and they ended up stealing. Studies by Lauristen (1993) support the above findings. He propounded that poverty is the overarching cause of many of the other structural and functional family factors including juvenile delinquency. Parents who are poor do not have the money to provide the same opportunities for their children as more prosperous families and this has increased the likelihood of their children developing into juvenile delinquents

Also the study found that a child's neighbourhood or home environment may be a causal factor in influencing children to commit crime. For example looking at participant 4 , he was a street child and his environment seemingly played a major role in him becoming a delinquent. This assertion is supported by Zill (2003) who states that neighbourhood disorganization is related to increased crime.

\subsection{Do Pare nting Styles have a Dire ct Effect on Juvenile Delinquency?}

The study also indicated that certain styles of parenting increase the likelihood of a child to commit crime. Participant 5 stated that his father was really harsh on him and he would get punished sometimes for silly mistakes. This is supported by Fergusson et al (1992) who propounded that inconsistent discipline has been found as a significant, contributing factor to juvenile delinquency.

\section{Conclusions}

There are many pathways to delinquency and a variety of family circumstances contribute to negative or adverse behaviour in children. The study demonstrated that the probability of a child becoming delinquent increases rapidly as the number of family problems or risk factors increase. Hence, it is necessary to understand the family dynamics that influence the behaviour of the child since the family 
provides the first level of social contact for the child. Children who grow up in violent households are more aggressive and grow up more like ly to become involved in violence either as a victimizer or as a victim especially if they witness violent acts. Also factors such as excessive family conflict and marital discord and family disorganisation often have negative effects on the wellbeing of a child thereby having an influence in juvenile delinquency.In additionchildren who lack attachment in their early lives are likely to develop into juvenile delinquents. It was also concluded in this study that participants who came from poor families were at a higher risk of engaging in crime. Some families are struggling to generate an income and this has been shown in the study to be a causal factor of juvenile delinquency.

The study also indicated that certain styles of parenting increase the likelihood of a child to commit crime. Of all the child-rearing methods, poor parental supervision is usually the strongest and most replicable predictor of offending. Children who are neglected have a higher chance of becoming delinquents. The study also revealed that having an authoritarian parent who tends to emphasize rules and very harsh consequences also increases the probability of a child becoming a delinquent.

\section{LiMitations OF THE STUDY}

However, in treating these findings and conclusions readers should take note of the following methodological constraints; there could have been some bias on the part of the respondents since the issues that they were reporting on are sensitive issues related to crime. Although the respondents were volunteers who were assured of confidentiality and anonymity they might have had some kind of evaluation apprehension emanating from the uncertainties and suspicions they had of the researchers' intentions in a prison set-up. In addition, this research relied on self reports and the problems of self reports have been dealt with at length in psychology; not least among them being social desirability sets, that is, the desire to present oneself in a positive light.

\section{RECOMMENDATIONS}

In view of the above-mentioned shortcomings it is recommended that further quantitative research studies be conducted in order to better understand the breadth of the problem. As this research was qualitative in nature it had a small sample size and the research was limited to juvenile delinquents currently residing at Blue hills in Gweru. There is need for a more extensive research. Such studies may preferably visit homes for the participants to see for themselves the home environment and the parenting styles prevalent in the homes from which the delinquent children are coming.

The rehabilitation offered at Blue Hills should try as much as possible to involve theparents and caregivers of juveniles since it has been established the home environment and parenting styles play a part in influencing juvenile delinquency. The Social Welfare department together with the Ministries of Home Affairs and Women's Affairs should try and play a leading role in developing and promoting programmes that foster family cohesion, unity and good parenting styles in Gweru with such programmes being tried at national level if successfully tested in Gweru. Such a primary prevention approach to delinquency can be an effective way of combating delinquency.

\section{REFERENCES}

Brownfield, D., \& Sorenson, A.M. (1994). Sibling size and sibling delinquency. Deviant Behaviour.

Dyer, C. (1995). Beginning research in psychology: A practical guide to researchmethods and statistics. Oxford: Blackwell Publishers.

Baumrind, D. (1966). Child development, effects of authoritative parental control on childbehaviour. Bowlby, J. (1951).Mental care and child health. WHO Monograph Series, 2.

Farrington, D. P. (1991).Childhood aggression and adult violence: Early precursors and later life outcomes. Hillsdale, NJ: Lawrence Erlbaum.

Farrington, D. (1991). Advancing knowledge about co-offending: Results from a prospective longitudinal survey of London males. Journal of Criminal Law \& Criminology, 82, 360-395.

Farrington,D. P. (1992). Juvenile delinquency. London, UK: Routledge.

Farrington, D. P., \&Lœber, R. (1999).Historical and geographical influences on Psychopathology Edited by Patricia Cohen, Cheryl Slomkowski, Lee N. Robins(pp. 299-329). Oxford: Routledge

Farrington, D. P., Jolliffe, D., Loeber, R., Stouthamer-Loeber, M., \& Kalb, L. M. (2001).The concentration of offenders in families, and family criminality in the prediction of boys' delinquency. Journal of adolescence, 24(5), 579-96 
Fergusson, D. M.,Horwood, L. J., \& Lynskey, M. T. (1992).. Family change, parental discord and early offending. Journal of Child Psychology and Psychiatry. 33, (6),1059-1075

Fischer, D. G.(1984). Family size and delinquency: Perceptual and Motor Skills.

Grove, W. M., Eckert, E. D., Heston, L.,Bouchard, T. J., Segal, N., \& Lykken, D. T. (1990).

Biological Psychiatry: Heritability of substance abuse and antisocial behavior: A study of monozygotic twins reared apart.

Herrenkohl, T. I., Maguin, E., Hill, K. G., Hawkins, J. D., Abbott, R. D., \& Catalano, R. F. (2000). Developmental risk factors for youth violence. Journal of Adolescent Health, 26, 176-186.

Juby, H., \& Farrington, D.P. (2001). Disentangling the link between disrupted families and deliquency. British Journal of Criminology, 41, 22-40.

Juvenile Delinquency: World YouthReport, 2003

Kolvin, I., Miller, F. J. W., Fleeting, M., \& Kolvin, P. A. (1988b). Social and parenting factors affecting criminal-offence rates: Findings from the Newcastle Thousand Family Study (19471980). British Journal of Psychiatry, 152, 80-90.

Lauritsen, J. L. (1993). Sibling resemblance in juvenile delinquency: Findings from the National Youth Survey. Criminology, 31,387-409.

Omboto, G., Onyango, J., Ondiek O. Ayugi, O. (2013) Factors influencing youth crime and juvenile Delinquency. International Journal of Research in Social Sciences 1, (2), 1-19

Smith, C. A., \& Stern, S. B. (1997). Delinquency and antisocial behavior: A review of family processes and intervention research. Social Service Review, 71,382-420.

The World youth report, 2003

Widom, C. S. (1989). The cycle of violence. Science,244, 160-166.

\section{AUTHORS' BIOGRAPHY}

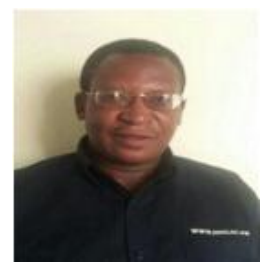

Benjamin Mambende, is a licensed educational psychologist. He hasworked as a government psychologist, seniortraining officer and institute managerin the Zimbabwe Public ServiceCommission. To add on, Benjamin has served as Psychology and Counselling lectureratthe Zimbabwe Open University and theMidlands State Universitywhere he is currently based. He has research interests in developmental,social and human resource psychology.

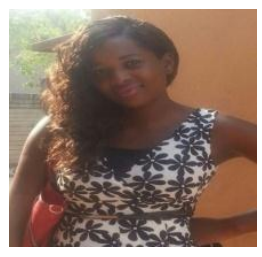

Thelma Nyandoro, is a psychology graduate. She has worked as a helping professionaland she has a passion in working with children and adolescents.

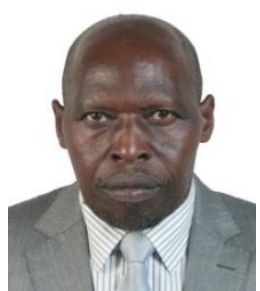

Le vison Maunganidze, is a licensed educational psychologist. He has worked as a government psychologist, national psychology programmes leader, senior lecturer, chairperson for social sciences Department and Executive Dean of Students and Support in the Zimbabwe Open University. In addition, Levison has served as a Psychology lecturer at the University of Zimbabwe and Women's University in Africa and senior psychology lecturer at the University of Venda and Midlands State University where he is currently based. He has research interests in child/adolescent development, performance measurement, psycho-educational assessments, HIV and AIDS orphans and vulnerable children, inclusive education stress and epistemological beliefs of students.

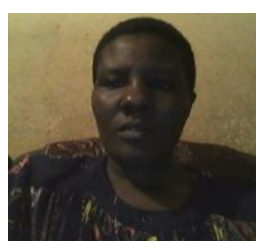

Sawuti Abigirl, is a Master of Science in Student Affairs graduate (Midlands State University) and a Bachelor of Science in Counselling (Zimbabwe Open University). She has served asa school Counsellor, senior teacher, head of Guidance and Counselling department, Boy/Girl empowerment officer at Katsenga Secondary school in Zimbabwe where she is currently based. She holds a Diploma in Education (Mutare Teacher's College) and a Certificate in Basic Sign Language (Sunrise Sign Language Academy).She is also a passionate researcher on issues to do with freshman and sophomores development. 